УДК 811.161 .2

DOI: https://doi.org/10.17721/APULTP.2020.41.105-118

\author{
Maiia B. Bulakh \\ ORCID ID: 0000-0002-0857-7256
}

\title{
INTERNET MEME AS A MEANS OF INTERTEXTUALITY
}

\begin{abstract}
The article considers the features of meme as a genre of Internet communication. The author focuses on the characteristics of the Internet meme as a means of intertextuality. The main attention is paid to the types and sources of intertextuality of memes in the Ukrainian-language Internet. In the last few years there has been a growing interest in study of new internet genres. To the author's knowledge, Ukrainian internet meme has been scarcely investigated from the point of view of intertextuality. The relevance of this work is due to the fact that Internet memes in the Ukrainian media are insufficiently explored. In particular, the category of intertextuality of memes has been poorly studied. This paper presents a new look at a previously unexplored aspect of intertextuality in Internet memes of the Ukrainian-language segment of the Internet. The purpose of this article is to identify and describe the features of the implementation of intertextuality in Internet memes. The author defines the Internet meme as a unit of Internet discourse, which is characterized by a combination of standard in form and expression in meaning. In this paper, the scholar describes meme as an illustration and a text to it. Due to their nature, memes are concentrated information in a vivid form. The material for the study is Internet memes from social networks of the Ukrainian-language Internet, such as Facebook, Instagram, Twitter. In order to study intertextuality in internet memes the author uses intertextual analysis and continuous sampling method. This allowes to explore the intertextual basis of Internet memes. The research shows that the nature of the intertextuality of Internet memes is diverse. The author outlines that prototexts of Internet memes are precedent names, statements, texts and situations. The paper describes the types of precedent texts, as well as the mechanisms of intertextuality. The author separately considers the functions of precedent texts in memes. The results show that the main functions of Internet memes are a means of creating comic effect, popularization through introduction into the global context, aesthetic effect, concentrating information and intellectual play. Research on intertextuality in Internet memes appears
\end{abstract}


fully justified as it is still insufficiently studied. The conclusions state that intertextuality is realized in Internet discourse, because Internet genres are interconnected and interactive. Duplication of the meme supports its precedent. Today, all texts on the Internet are interconnected by hypervocations, and the Internet has become one hypertext in the modern information and communication environment.

Key words: internet meme, intertextuality, mass communication, precedent text, internet communication.

Information about author: Bulakh Maiia Bohdanivna - PhD; assistant of the department of stylistics and language communication; Institute of philology; Taras Shevchenko National University of Kyiv.

E-mail: bulakh1@ukr.net

\section{Булах М.Б. \\ ORCID ID: 0000-0002-0857-7256 \\ ІНТЕРНЕТ-МЕМ ЯК ЗАСІБ ІНТЕРТЕКСТУАЛЬНОСТІ}

Анотація. Запропонована стаття присвячена аналізу властивостей інтертекстуальності інтернет-мема. Інтернет-мем розглядаємо як особливий жанр інтернет-комунікаџії, що має яскраву лаконічну форму та конщентрований зміст. У роботі ми зосередились на інтертекстуальній особливості мемів, адже меми дуже часто творяться на основі прецедентних текстів. Такими прецедентними феноменами можуть виступати текст художньої літератури, прецедентна ситуація, прецедентне ім'я або назва, інший мем. Відсилка до іншого тексту може бути як у формі, так і у вербальному наповненні, вона може бути очевидною і прихованою. Розглядаючи феномен інтертекстуальності та прецедентності, ми базувалися на роботах європейських дослідників Ю. Крістєвої, Р. Барта, Ж. Дерріди, що представляють підхід до явища інтертекстуальності, коли кожен текст уявлясться як частина універсального тексту. У нашій роботі ми розглядаємо інтертекстуальність як міжтекстову взаємодію, за якої відбувається свідоме використання міжтекстових зв'язків між новим текстом і прототекстом. Інтертекстуальність зреалізована в Інтернет-дискурсі, адже Інтернет-жанри взаєпов'язані та інтерактивні. Така риса інтернет-мема, як дубльованість, підтримує його прещедентність. Сьогодні усі тексти в 
Інтернеті взаєпов'язані гіперпокликаннями, і Інтернет став одними гіпертекстом у сучасному інформачійно-комунікаційному середовищі. У роботі був використаний метод суцільної вибірки для добору матеріалу та метод інтертекстуального аналізу. Матеріалом запропонованої статті стали украӥнські інтернет-меми з соціальних мереж інтернету, таких як Фейсбук, Інстаграм, Твітер. Актуальність нашої роботи ми вбачаємо у тому, що інтернет-меми як жанр, щзо постійно розвивається і створюється, мало досліджений в украӥнських наукових роботах. Зауважимо, що зокрема мало досліджена така їх категорія, як інтертекстуальність. Мu запропонували функиії прецедентних феноменів в інтернет-мемах, виокремивши такі: засіб створення комізм, засіб популяризаиії за рахунок введення у глобальний контекст, засіб створення естетичного ефекту, засіб концентрачії інформації, засіб створення інтелектуальної гри і загадки.

Ключові слова: інтернет-мем, інтертекстуальність, масова комунікація, прецедентний текст, інтернет-комунікація.

Інформація про автора: Булах Майя Богданівна -кандидат філологічних наук; асистент кафедри стилістики та мовної комунікаџї;; Інститут філологї; Київський наџіональний університет імені Тараса Шевченка.

Електронна адреса: bulakh1@ukr.net

\title{
Булах М.Б. \\ ORCID ID: 0000-0002-0857-7256 \\ ИНТЕРНЕТ-МЕМ КАК СРЕДСТВО ИНТЕРТЕКСТУАЛЬНОСТИ
}

\begin{abstract}
Аннотация. Данная статья посвящена анализу свойств интертекстуальности интернет-мема. Мы рассматриваем интернетмем как особый жанр интернет-коммуникации, который имеет яркую лаконичную форму и концентрированный смысл. B работе мы сосредоточились на интертекстуальной особенности мемов, ведь мемы очень часто возникают на основе прецедентных текстов. Такими прецедентными феноменами могут выступать тексть художественной литературы, прецедентные ситуации, прецедентные имена или названия, другие мемы. Отсылку к другому тексту можно увидеть как в форме, так и в вербальном наполнении, она может быть
\end{abstract}


очевидной и скрытой. Рассматривая феномен интертекстуальности и прецедентности, мы базировались на работах европейских исследователей Ю. Кристевой, Р. Барта, Ж. Дерриды, представляющие такой подход к явлению интертекстуальности, при котором каждый текст рассматривают как часть универсального текста. В этой работе мы понимаем интертекстуальность как межтекстовое взаимодействие, при котором происходит сознательное использование интертекстовых связей между новым текстом и прототекстом. Интертекстуальность реализована в интернет-дискурсе, ведь интернет-жанры взаимосвязаны и интерактивны. Такая черта интернет-мема, как дублированность, поддерживает его прецедентность. Сегодня все тексты в Интернете связаны гиперссылками, а интернет стал одним гипертекстом в современной информационно-коммуникачионной среде. В работе был использован метод сплошной выборки для отбора материала и метод интертекстуального анализа. Материалом предлагаемой статьи стали украинские интернет-мемы из соииальных сетей интернета, таких как Фейсбук, Инстаграм, Твиттер. Актуальность нашей работьы в том, что интернет-мемы как жанр, который постоянно развивается, мало исследован в украинских научных работах. Заметим, в частности мало исследована такая их категория, как интертекстуальность. Mbl рассмотрели функиии прецедентных феноменов в интернет-мемах, выделив следующие: средство создания комизма, средство популяризачии за счет введения в глобальный контекст, средство создания эстетического эффекта, средство кониентрации информачии, средство создания интеллектуальной игры и загадки.

Ключевые слова: интернет-мем, интертекстуальность, массовая коммуникация, прецедентный текст, интернет-коммуникация.

Информация об авторе: Булах Майя Богдановна - кандидат филологических наук; ассистент кафедра стилистики и языковой коммуникации; Институт филологии; Киевский национальный университет имени Тараса Шевченка.

Электронный адрес: bulakh1@ukr.net

The development of socio-cultural processes in the information age has led to the emergence of new genres on the Internet. In our article we will continue [1] a series of studies of such a special genre in the Ukrainian Internet sphere as meme. It is well-known that memes are part of an online subculture, a virtual mass discourse. The relevance of 
this work is due to the fact that Internet memes in the Ukrainian media are little studied, and especially little studied is their category, such as intertextuality. However, there is still a need for research on Internet memes as an important part of mass communication.

It is common knowledge that Internet memes are units of Internet communication, the main property of which is conciseness and virality. In spite of to the capacity of rich information, placed in a bright and attractive form, memes spread quickly on the Internet, and in particular on social media. As for the form of the Internet meme, it differs from the usual caption image to a viral video.

Generally speaking, memes are a media reaction to new events in society. The development of modern communication channels is intensifying the emergence of new memes. Multi-channel Internet media, which are social networks, create and produce them not only verbally but also visually. Memetic genres are especially active in social networks such as Twitter, Instagram, Facebook, YouTube.

The genre of Internet meme is an integral part of the media space, and undoubtedly reflects the intertextuality of Internet text. As Russian researcher of media memes S. Kanashina noted in her study "Internet meme as media text", "among the characteristics of the Internet meme as media text we can distinguish intertextuality, interactivity, hybridity and pattern" [2, p. 108].

The paper used the method of continuous sampling for material selection and the method of intertextual analysis. This allowed us to explore the intertextual basis of Internet memes. The material of the proposed article was Ukrainian Internet memes from social networks such as Facebook, Instagram, Twitter.

In our paper the focus of attention is on intertextuality as a basic characteristic of media texts. After all, intertextuality, as we understand it, is intertextual connections connected by calls to each other. The World Wide Web is therefore metaphorically called a network, because all texts (in the broadest sense) on the Internet form a web of interdependent texts open to multichannel interconnections. Such Internet culture, according to researcher O. Krasnoyarova "is a plurality of texts, meanings, open to creative productive play of generation of meanings, open to a plurality of polyphonic dialogues that permeate the media space" [4, p. 91]. 
We believe that memes are an organic part of Internet culture and are part of a system of typical Internet memes that create viral series of memes. Internet memes can exist in Internet culture as an autonomous unit and as a component of blogs, advertising, portals, online publications. The realm of online texts is hypertext, where all texts are linked and one text is the path to a thousand others. Therefore, even sometimes on the border of such intertextual interaction it is difficult to trace where a new text begins and another's is fragmented.

As for the concept of intertextuality, we understand intertextuality as an intertextual interaction in which there is a conscious use of intertextual connections between the new text and the prototext. A broad understanding of intertextuality, when each text is considered part of a universal text, was presented in the papers of Y. Kristeva, R. Barth, J. Derrida. In her "Semiotics" (1969), Y. Kristeva described intertextuality as an infinite process in which previous and new texts are reproduced and interact $[5 ; 6]$.

A well-known Ukrainian researcher O. Selivanova defines the precedent phenomenon as "a component of knowledge, the designation and content of which are well-known to representatives of a certain ethnocultural community, relevant and used in cognitive and communicative terms. Types of precedent phenomena are name (individual name of a famous person, character of a work, artifact); situation (significant event that actually took place in the life of an ethnic group and civilization); text (a popular work, actualized in other texts, the return to which is guided by the mechanisms of intertextuality)" [7, p. 492]. Thus, precedent names can be precedent names, precedent situations, precedent texts. The source of the intertextuality of an internet meme can be: a text of fiction, a precedent situation, a precedent name or title, another meme.

Our research has shown that the Internet meme is very often based on a precedent phenomenon and becomes a precedent phenomenon in itself. Being produced and reduplicated in different contexts, meme becomes a modified copy of itself. We must point out that the precedent text also tends to be transformed into memes and reinterpreted. 
It is worth noting that in popular media publications aimed at a mass audience, the selection of precedent texts is often reduced to a limited range of mass, obvious and easily guessed texts and situations. Usually, memes are based on current events, pop images, "political icons, popular figures and historic (canonical) images in different types" [8, p. 72].

Analyzing the memes of the Ukrainian segment of the Internet, we can see the following main types of precedent phenomena.

1. Precedent events. Such are the events of the last year, such as the pandemic and historical events - the Revolution of Dignity, important facts from history, the presidential election and similar defining facts from the life of Ukraine.

2. Precedent slogans. We are talking about mottos and slogans from political campaigns of local elections and presidential elections.

3. Precedent names and images. These are popular modern figures and historical figures. Contemporaries may include politicians, athletes, pop stars,

4. Precedent works of art. These include works of fiction, paintings, lyrics.

5. Precedent memes. They are often memes that first appeared in the American or European segments of the Internet, or can be local.

Obviously, the reason for this is an attempt to focus on the level of knowledge of the recipient. It is assumed that the average reader does not have extensive encyclopedic knowledge and highly developed intellectual competence. We believe that the use of means of intertextuality develops the reader's sense of speech and can expand his awareness, although, of course, this is not a priority. The reader's ability to recognize, comprehend and interpret the meaning of the text occurs only when the background knowledge of the author and the recipient are shared.

It is interesting to note that one of the sources of Ukrainian memes precedent is samples of texts of Ukrainian literature, or biographical facts of poets and writers. Here are some examples from the Instagram public "Fine memes about Ukrainian literature". In particular, several precedent sources intersect on one of the memes, namely the film "Joker" in 2019 and Pavlo Tychyna's poetry. The 
poems "Ви знаєте, як липа шелестить" and "Партія веде" are mentioned in comparison with two photos from the movie "Joker", illustrating the hero's mood from calm and satisfied to melancholy despair. Of course, to understand this meme, you need to know the history of Ukrainian culture of the twentieth century, as well as the plot of the movie "The Joker".

As for literary memes, the most popular heroes of them are Taras Shevchenko, Ivan Franko, Lesya Ukrainka, Mykhailo Kotsyubynsky. Moreover, memes often mention their most famous works "Садок вишневий коло хати", "Каменярі", "Intermezzo". Or another example where Ukrainian writers and American cinema collided. Lesya Ukrainka and Olga Kobylyanska are easily guessed in the images of famous heroes of the film "Pulp Fiction" of 1994.

Unfortunately, the precedent, which gave rise to many genres on the social network, was a pandemic. Analyzing the Internet memes of 2020, we undoubtedly see a reflection of the situation around the world, and in particular in Ukraine. This is a COVID-19 pandemic.

During the period when laboratory-confirmed cases of COVID-19 began to be recorded throughout Ukraine, the network joked about the "phenomenon" of the Mykolayiv region and the city of Mykolayiv, where no case of the disease was officially recorded. Active users of social networks have responded to this fact with numerous photo frogs and memes, such as a reinterpreted poster from the movie "Catch Me If You Can" (2002).

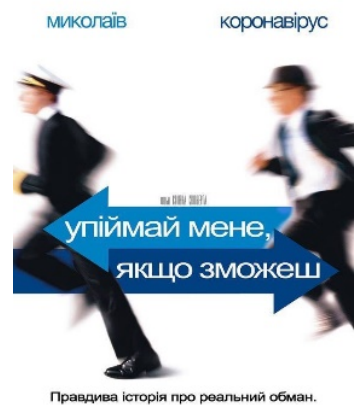

Figure 1. Catch Me If You Can 
Another topic that many memes have been dedicated to in 2020 is "colossal change", which leads to the self-isolation of people and the reduction of their impact on the environment. We draw attention to a meme with historical allusions "Because of quarantine, the Kyiv streets were cleared, and the Government of the Ukrainian People's Republic in exile returned to the Teacher's House."

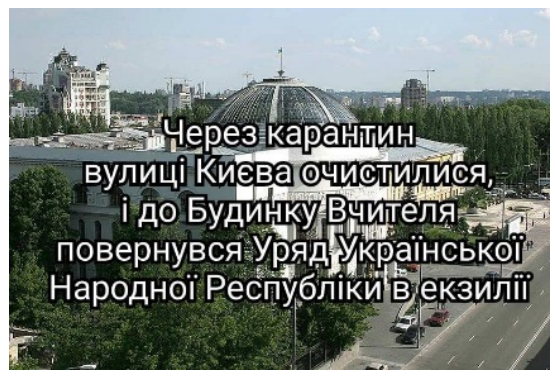

Figure 2. The Kyiv streets were cleared, and the Government of the Ukrainian People's Republic in exile returned to the Teacher's House

The situation led to the cancellation of all public events, which the reporters illustrated with a meme alluding to the mural "The Last Supper" by Leonardo da Vinci, which lacks all the characters in the picture and instead has the inscription "Canceled".

The situation with coronavirus and quarantine, despite the seriousness of the subject, caused a wave of memes, jokes and photo frogs on the network. In particular, about the professions that have the opportunity to earn a lot during the quarantine period. For example, a meme based on an illustration from the Disney cartoon "Duck Stories" illustrates how couriers of delivery services bathe in gold.

However, meme is a genre of online communication that combines verbal and visual components. We believe that sufficient understanding of the Internet meme is possible only taking into account both graphic and verbal semantic components. Research has shown that the graphic component of the Internet meme is often an allusion to precedent text, which enriches the meaning of the meme and introduces it into the system of hyperlinks. 
In the article "Internet meme as a media text" it has been suggested that the Internet meme is characterized by a pattern, which is implemented in its standardized form. This form facilitates the perception of memes, saves language and cognitive resources. Follow assumption seems to be reasonable. "The stereotypical nature of Internet memes indicates the general trend of the modern information space to compression and reduction at the structural and semantic levels" [2, p. 110-111].

We understand intertextuality as intertextual interaction, the correlation of one text with another. As we can see, intertextuality is a necessary characteristic of the Internet meme, which is manifested both in its formation, often based on precedent, and in its use, when it itself becomes a precedent and is reduplicated many times. In this case, the prototype and the copy are connected by intertextual links. As mentioned earlier, Internet memes tend to be serial. This means that on the basis of a successful meme, which becomes a model, dozens of new ones are created. For example, a meme with I. Franko and cats and a collage with T. Shevchenko. The latest series of memes to go viral is a flash mob consisting of four photos linked to different social networks: Linkedin - a strict portrait, Facebook - a family photo, Instagram - a gorgeous photo, Tinder - an attractive photo. Such a collage was created for prominent figures of Ukrainian culture, one of which we cite as an example - the image of Taras Shevchenko.

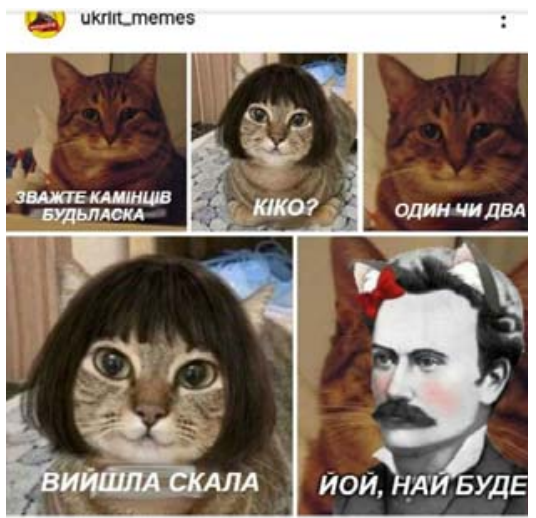

Figure 3. Meme with I. Franko

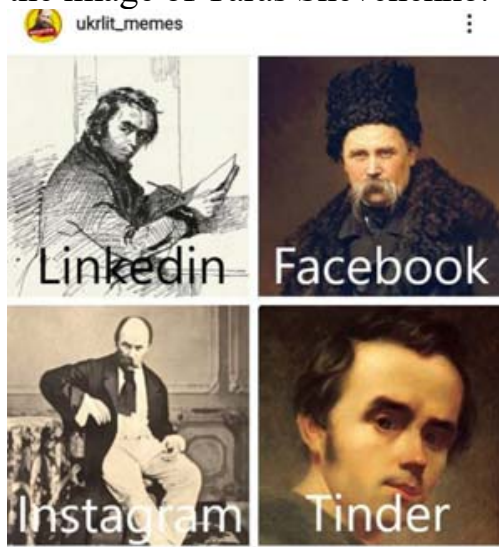

Figure 4. Viral meme with Taras Shevchenko 
As for the functions of intertext in Internet memes, based on the work of researcher S. Kanashina [3, p. 124], who figured out the functions of precedent phenomena in Internet memes, we, in turn, proposed such as:

\section{Means of creating comic effect.}

To illustrate, let's give an example of the reaction of social network users to the concrete structure on Kyiv's Independence Square. It was installed for the holiday on March 8 and looked like a huge snowdrop. Concrete snowdrops in the network were immediately called the flowers of evil, alluding to the collection of poems by the French symbolist poet Charles Baudelaire "Flowers of Evil". A meme depicting the cover of a book with a photo from Independence Square in Kyiv has appeared on Facebook.

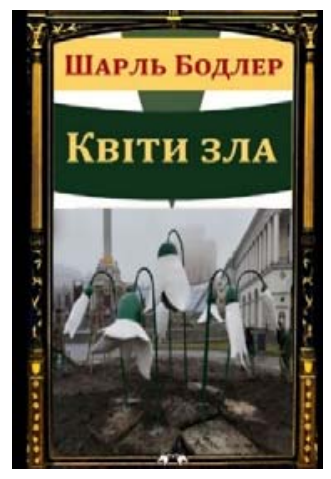

Figure 5.

Flowers of Evil on on Independence Square in Kyiv

\section{Means of promotion through introduction into the global context.}

In order to promote the meme, the author can deliberately choose precedent themes, figures, or use viral series of memes. The precedent connects the text with many other texts, thus creating a network of memes. This confirms the fact that many Ukrainian memes are based on well-known memes of American or European origin. In particular, among those that we have offered as an 
illustration in our article are a meme with I. Franco and cats, a meme with a fresco by Leonardo da Vinci, a meme flashmob with photos from different social networks.

\section{Means of creating an aesthetic effect.}

The aesthetic motivation of the precedent text in both formal and verbal expression of the meme adds to this genre emotionality and expressiveness. The richness of symbols and artistic background, which is manifested in allusions to fiction and cinema, creates a multi-layered multicultural context. Thus, the new meme realizes the creative potential of the author and the audience. A good example of this function will be a meme, where the images of famous heroes of the film "Pulp fiction" by K. Tarantino depict Ukrainian writers Lesya Ukrainka and Olga Kobylyanska. In our opinion, such a militant, aggressive image symbolizes the struggle of the Ukrainian feminist movement, the symbols of which, of course, became these writers.

\section{Means of creating an intellectual game and puzzle.}

The use of the precedent phenomenon requires a certain readability and a broad outlook to understand some memes, which increases the awareness of the audience. When the reader uses his erudition to read the meme, he rises in his eyes, goes to the level of elite readers. In particular, the meme about concrete flowers on Independence Square in Kyiv and a collection of poems by S. Baudelaire already mentioned in this article.

Hidden precedent can also be a kind of secret code, which is sorted by the principle for identification friend-foe. For example, it is possible to stratify the audience by age, interests, political preferences, level of education.

\section{Means of concentrating information.}

The precedent phenomenon puts the meme in a broad context, thus concentrating a system of connections and a rich background. This saves the reader's cognitive resource and space in the media text. Much of the daily conversation has moved to the Internet, so too long texts are inferior to concise situational-contextual memes. Their perception does not require the reader much concentration to master a significant amount of information. In particular, it works 
well in memes on current topics, one of which in 2020 was the situation with coronavirus and quarantine. Any mention of the disease, doctors, medical masks in memes actualize the external context and save verbal effort. For example, the series of memes we mentioned earlier "Nature has been cleansed in quarantine" or memes about professions that have the opportunity to earn a lot during the quarantine period.

Conclusions. Our work has led us to conclude that Internet memes are indeed often based on precedent phenomena and intertextuality. We explain this by the fact that the sphere of Internet communication determines the interpenetration and interaction of all texts. It is also due to the fact that the meme is a genre that combines expression and standard. This online genre is a combination of easy to play, patterned reduplicated form and bright, often comic content. The reference to another text can be both in form and in verbal content, it can be obvious and hidden.

In our future research we intend to concentrate on other peculiarities o Internet meme. We see prospects in further study of the genre of Internet meme, given the frequency of its appearance in the Ukrainian-language Internet space.

\section{REFERENCES}

1. Bulakh, M. (2019). Aspectology of meme research [Aspektologija doslidzhen' memiv]. Naukovyj visnyk Mizhnarodnogo gumanitarnogo universytetu, 39(3), 104-107. https://doi.org/10.32841/24091154.2019.39.3.23 [in Ukrainian].

2. Kanashyna, S. (2019). Internet meme as media text [Internet-mem kak mediatekst]. Izvestija Saratovskogo universiteta. Novaja serija. Serija: Filologija. Zhurnalistika, 1(19), 107-112. https://doi.org/10.18500/ 1817-7115-2019-19-1-107-112 [in Russian].

3. Kanashyna, S. (2018). Internet meme and precedent phenomenon [Internet-mem i precedentnyj fenomen]. Vestnik TGPU, 4 (193), 122-127. https://doi.org/10.23951/1609-624X-2018-4-122-127 [in Russian].

4. Krasnojarova, O. (2015). Text and media text: the problem of concept differentiation [Tekst i mediatekst: problema differenciacii ponjatij]. Voprosy teorii $i$ praktiki zhurnalistiki, 4(1), 85-100. https://doi.org/ 10.17150/2308-6203.2015.4(1).85-100 [in Russian]. 
5. Kristeva, J. (2015). Semiotics [Semiotika: issledovanija po semanalizu]. Moskva: Akademicheskij proekt. [in Russian].

6. P'ege-Gro, N. (2008). Introduction to the theory of intertextuality [Vvedenie $\mathrm{v}$ teoriju intertekstual'nosti]. Moskva: Izdatel'stvo LKI [in Russian].

7. Selivanova, O. (2006). Modern linguistics: terminological encyclopedia [Suchasna lingvistyka: terminologichna encyklopedija]. Poltava: Dovkillja [in Ukrainian].

8. Barlas Bozkuş, S. (2016). Pop Polyvocality and Internet Memes As a Reflection of Socio Political Discourse of Turkish Youth in Social Media. Global Media Journal, 6, 44-74. https://doi.org/10.17361/ UHIVE.20161016628 [in English].

\section{RESOURCES}

(a) https://ms.detector.media/sotsmerezhi/post/24298/2020-03-06betonni-proliski-na-maidani-nezalezhnosti-u-merezhi-peretvorili-nafotozhabu/

(b) https://ms.detector.media/sotsmerezhi/post/24479/2020-04-12-kubanpovernulasya-do-skladu-ukraini-krashchi-memi-pro-onovlennya-prirodi-pidchas-karantinu/

(c) https://www.instagram.com/ukrlit_memes/?hl=ru

(d) https://twitter.com/ukrlit memes

(e) https://ms.detector.media/sotsmerezhi/post/24316/2020-03-12-trebaprosto-perestati-zarazhatisya-u-sotsmerezhakh-zhartuyut-pro-koronaviruskarantin-i-grechku/

(f) https://www.instagram.com/fmupl/?hl=ru

Дата надходження до редакції - 06.10.2020 Дата затвердження редакцією - 27.10.2020 